\title{
Clinicopathological study of endometrium in peri and postmenopausal women in a tertiary care hospital in Eastern India
}

\author{
Himel Bera ${ }^{1}$, Subhalakshmi Mukhopadhyay ${ }^{2}$, Tanushree Mondal ${ }^{3}$, Koushik \\ Dewan $^{4}$, Arnab Mondal ${ }^{5}$, Swapan Kr. Sinha ${ }^{6}$ \\ ${ }^{I}$ (Demonstrator, Department of Pathology, Medical College, Kolkata-73, WBUHS, India) \\ ${ }^{2}$ (Professor, Department of Pathology, Malda Medical College, Malda, WBUHS, India) \\ ${ }_{3}^{3}$ (Assistant Director of Medical Education, Swasthya Bhawan, Kolkata-91, India) \\ ${ }^{4}$ (Senior Resident, Chittaranjan National cancer Institute, Kolkata-26, India) \\ ${ }_{5}^{5}$ Assistant Professor, Department of Obstretics \& Gynaecology, KPC Medical College, Kolkata, India) \\ ${ }^{6}$ (Professor, IQ City Medical College, Durgapur, West Bengal, India)
}

\section{Introduction}

Uterus weighs $50 \mathrm{gms}$ and measures about about $8.0 \mathrm{~cm} . \times 6.0 \mathrm{~cm} . \times 3.0 \mathrm{~cm}$ in normal nulliparous reproductive women and varies with age and parity. Uterine cavity is lined by a specialized form of tissue endometrium which has extra-ordinary sensitivity to the ovarian secretion in conjunction with its overwhelming capacity to regenerate after the menstruation. The deeper layer of endometrium i.e. stratum basale (deeper $1 / 3^{\text {rd }}$ ) is not shed during menstruation. Rather it is responsible for the regeneration of the endometrium following menstruation $^{1,2}$. The endometrium normally varies greatly in thickness and measures from $0.5 \mathrm{~mm}$. to $5 \mathrm{~mm}$. because of increase in thickness and cyclic changes that occur during the reproductive years of a woman. The extremes of reproductive life (after menarche and perimenopause) are characterized by a higher percentage of anovulatory or irregularly timed cycles ${ }^{3,4}$. By convention it is taken that perimenopasual period starts after the age of 40 years $^{5}$. Also the term amennorrhoea is used to denote the absence of menstruation in a lady for a continuous stretch of 12 months. The average age of menopause varies greatly in Indian women. It roughly ranges from 44 years to round about 50 years. But in day to day practice getting menstruating patients even after 53 years is not an unusual occurrance

During the perimenopausal era the different types of bleeding irregularities supervene such as polymenorrhoea, menorrhagia, metrorrhagia, menometrorrhagia, cryptomenorrhoea or hypomenorrhoea, oligomenorrhoea, contact bleeding, dysmenorrhoea etc. These menstrual irregularities often arise when a women proceeds towards menopause and after menopause i.e. in women over 40 years of age. These occur as a consequence of different histopathological changes in the endometrium. Amongst them the important ones are endometrial carcinoma, endometrial hyperplasia, endometrial polyp, endometrial stromal tumour, endometritis (acute and chronic), effects of exogenous hormone (e.g. longstanding estrogen therapy, tamoxifen therapy), adenomyosis, leiomyoma, leiomyosarcoma etc. With usual waning of oestrogen secretion at perimenopausal period the endometrium may specially undergo dramatic changes. The histopathologic study of endometrium in peri as well as in postmenopausal women thus gives us a chance to probe into the matter further.

\section{Material And Methods}

The present study was conducted mainly in the Department of Pathology of Medical college, Kolkata in collaboration with the Department of Gynaecology and Obstetrics of the same institution during the time period of December 2011 to November 2012. Extensive histopathological correlation was done along with history and imaging.

\section{Results And Analysis}

Total 120 patients were studied. Among them 51 women achieved menopause and 69 of them did not reach menopause; but all of those 69 patients were in perimenopausal period (e.g. they were aged 40 years or above). Among the 69 cases of perimenopausal women, we found as much as 51 patients to present with abnormal pattern of menstrual bleeding. Rest 18 perimenopausal cases present with complaints other than abnormal pattern of uterine bleeding (e.g. abdominal lump, per vaginal discharge, dysparenuia etc.). Among the 51 cases of postmenopausal women, we found as much as 31 patients to present with abnormal pattern of menstrual bleeding. Rest 20 postmenopausal cases present with complaints other than abnormal pattern of uterine bleeding(e.g. abdominal lump, per vaginal discharge, dysparenuia etc.). In this study maximum cases 
were in the age group of 40-45 years,50 cases.( $41.67 \%)$.The second largest category belonged to the age group of $46-50$ years, 42 cases $(35.00 \%)$ of the study population. Other groups were $<40$ years (6 cases), 51-60 years (15 cases), 61-70 years ( 7 cases).

Among the 69 cases of perimenopausal women largest subdivision was made by the women aged between $40-45$ years. This subdivision included 40 cases $(57.97 \%$ of all the perimenopausal women). We encountered only 4 cases (5.80\% of all the perimenopausal women) aged 51 years and above who were still menstruating. 25 cases (36.23\% of all the perimenopausal women) were between $46-50$ years of age.

Regarding the age distribution of the postmenopausal women 17 cases $(33.33 \%$ of the all postmenopausal women in this study) were between $46-50$ years. This was the largest subdivision in this group. Only 6 cases (11.76\% of the all postmenopausal women in this study) achieved menopause before they reached 40 years of age.

Among the whole study population 18 cases (15.00\%) achieved menarche at the age of 10 years. 24 cases $(20.00 \%)$ achieved it at 11 years. Maximum cases (29 patients) started menstruation at the age of 12 years (24.16\%). It started at the age of 13 years and 14 years respectively in 22 and 21 cases (18.33\% \& 17.50\%). 5 cases $(4.17 \%)$ started menstrual cycle at the age of 15 years. Only one case achieved menopause as late as at the age of 16 years. All over the average age of menopause in the study was 12.19 years.

Among the total 99 cases of abnormal uterine bleeders, most common pattern of bleeding abnormality observed was menorrhagia. It was experienced in as high as 38 patients comprising of $38.38 \%$ of the abnormal bleeder group and $31.67 \%$ of the patients in the whole series. We got 15 cases $(18.29 \%$ of the abnormal bleeder group and $12.50 \%$ of the patients in the whole series) of postmenopausal bleeding in the whole series. The nonbleeder group, there were a total of 21 cases. Uterine prolapse was found in 9 cases. Infertility and habitual abortion was the main complaint in 6 cases. Lower abdominal lump and pain were the other complaints. As a whole $17.50 \%$ patients in the study reported with complaint other than bleeding.

We included both endometrial tissue obtained both from D \& C operation and from hysterectomy specimen. Among the total 120 samples, 67 were taken by D \& C operation (55.83\%). Rest 53 endometrium were obtained by hysterectomy $(44.17 \%)$.

In the present study we found a good amount of histopathological variation in the endometrium. There were 30 cases $(25.00 \%)$ of proliferative endometrium, 9 cases $(7.50 \%)$ of secretory endometrium, but only 2 cases $(1.67 \%)$ with irregular ripening. A bulk of 34 cases $(28.33 \%)$ were found to be in the group of atrophic endometrium. We encountered 2 cases (1.67\%) of endometrial tuberculosis, both the specimens were of total hysterectomies. Hyperplasia was detected in as much as 31 cases (25.83\%). Regarding the neoplastic process, we got 9 cases $(7.50 \%)$ of endometrial carcinoma and came across only one case $(0.83 \%)$ of endometrial stromal sarcoma.

In the present study, amongst the total 51 cases of postmenopausal women the predominant endometrial histopathological variant was atrophic endometrium. Its share was 25 cases $(49.01 \%)$. We encountered hyperplastic endometrium in 12 cases (23.52\%). Nonsecretory endomnetrium were found in 5 cases $(9.80 \%)$. There were 8 cases of endometrial carcinoma (15.69\%) and 1 case of endometrial stromal sarcoma $(1.96 \%)$.

In the present study, amongst the total 69 cases of perimenopausal women the predominant endometrial histopathological variant was proliferative endometrium. Its share was 25 cases $(36.23 \%)$. We encountered hyperplastic endometrium in 19 cases $(27.54 \%)$. There were 3 cases of endometrial carcinoma (4.34\%). 2 cases each of endometrial tuberculosis $(2.90 \%)$ and irregular (2.90\%) ripening of endometrium were found.

Amongst the 31 cases of hyperplasia there were 19 cases of simple endometrial hyperplasia. It constituted $61.29 \%$ of the hyperplastic group and $15.83 \%$ of the whole study population. There were 12 cases of complex endometrial hyperplasia which formed $38.71 \%$ of the hyperplastic group and $10.00 \%$ of the whole study population. Overall in the whole study population hyperplastic endometrium was found in $25.83 \%$ cases.Depending upon nuclear and cytologic atypia simple and complex hyperplasia can be divided in further four groups. Maximum cases were of simple hyperplasia without atypia (45.16\%). Minimum cases were of complex hyperplasia with atypia $(12.90 \%)$.

In ultrasonographic measurement of all the hyperplastic endometrium in this study we got 29 out of 31 cases where the endometrial thickness was more than $5 \mathrm{~mm}$. (93.54\%). We got only 2 cases $(6.46 \%)$ where there was histopathological evidence of endometrial hyperplasia, but the ultrasonographic support was lacking as the thickness was less than $5 \mathrm{~mm}$. In most of the cases the endometrial thickness was in the range of $5-8$ $\mathrm{mm}$. There share was 20 cases $(64.52 \%)$. In the rest proportion (9 cases)the endometrial thickness was more than $8 \mathrm{~mm}$. (29.02\%).

Among the 11 cases of endometrial carcinoma we found no case where the endometrial thickness was less than $5 \mathrm{~mm}$. The endometrial thickness was between $5-8 \mathrm{~mm}$. in 3 cases $(27.27 \%)$ and more than $8 \mathrm{~mm}$. in 8 cases $(72.73 \%)$. On an average the endometrial thickness was $9.0 \mathrm{~mm}$.

Among the 11 cases of endometrial 
adenocarcinoma we got 6 cases of endometrioid adenocarcinoma, 3 cases of papillary serous variety of adenocarcinoma, one each case of clear cell carcinoma and squamous cell carcinoma.

We studied the Body Mass Index (BMI) of the study population. 45 cases (37.50\%) were obese in this study. 35 patients $(29.17 \%)$ were in the overweight group. We also found that obesity is a frequent entity for postmenopausal women. 31 cases $(25.83 \%)$ were healthy people. 9 cases $(7.50 \%)$ were found to be underweight.

Among the study population there were 45 obese women. Endometrial hyperplasia was the predominant histologic variety in that group. It included 22 cases which constituted $48.89 \%$ of the obese population. 6 out of 11 cases $(54.55 \%)$ of endometrial carcinoma were found to be obese. Other histopathologic varieties are proliferative endometrium (17.78\%), secretory endometrium (6.67\%), atrophic endometrium (11.11\%). Only one endometrial stromal sarcoma encountered in this study was found to be obese. While studying the BMI of the endometrial carcinoma patients we found that 7 out of 11 cases of endometrial carcinoma were obese. Mean value of BMI in all the endometrial carcinoma cases was 32.76.In the whole study population of 120 cases we got 18 patients of diabetes mellitus (15.00\%). Among this diabetic group the predominant histologic variety was endometrial hyperplasia; which constituted 9 out of 18 cases (50.00\%). 4 cases out of 18 diabetic (22.22\%) patients had endometrial carcinoma. Other histologic varieties are proliferative, secretory and atrophic endometrium.

Among the 36 hypertensive patients in our study the most predominant histopathologic variety of endometrium was endometrial hyperplasia (38.89\%). 5 cases of endometrial carcinoma were hypertensive $(13.89 \%)$. Atrophic endometrium also encompassed a significant proportion (22.22\%).

\section{Discussion}

So, overall we found that abnormal utetrine bleeding was the most prevalent complaint of the perimenopausal and postmenopausal women in our study. It is very significant to note that amongst the total 15 cases of postmenopausal bleeding in this study 8 cases $(53.33 \%)$ were diagnosed to harbour carcinoma in their endometrium. Jilani et al. from Pakistan have provided a glimpse of the scenario of the Indian sub-continent. ${ }^{6}$ That study showed a high prevalence of malignant disorders e.g. 30\% (compared to 53\% in our study) in women with postmenopausal bleeding.

To investigate endometrial histopathology in a population of women presenting with postmenopausal bleeding Gredmark et al. conducted a prospective study with collection of data during an 18-month period. ${ }^{7}$ The peak incidence of endometrial carcinoma was found in women between 65 and 69 years of age. Their study showed: atrophic endometrium (50\%) to be the most predominant histopathological category; as we found very similar result in our workup. $49.01 \%$ of all the postmenopausal women harboured atrophic endometrium in our workup. Their finding regarding endometrial adenocarcinoma (8\%) and endometrial hyperplasia (10\%) were lesser in comparison to our result $(15 \%$ \& $23 \%$ respectively). Our finding regarding incidence of endometrial malignancy coincided other researchers particularly in the Indian sub-continent. Dawood et al. carried out a prospective observational study in the Fauji Foundation Hospital, Rawalpindi, Pakistan comprising of 167 cases presenting with postmenopausal bleeding. ${ }^{8} \quad$ They concluded that the overall incidence of malignancies in patients presenting with PMB is high $(16.00 \%)$, therefore, it needs to be taken seriously and requires prompt and thorough investigations.

Lee et al. conducted a retrospective study among 163 cases of symptomatic postmenopausal women those attending the gynaecological clinic in the local population. ${ }^{9}$ They encountered endometrial malignancy in $11 \%$ patients (15\% in our study). They concluded that as the associated incidence of malignancy is high in postmenopausal age; a thorough diagnostic evaluation is mandatory.

Mukhopadhyay et al. also similarly found a significant amount of endometrial hyperplasia in the perimenopausal women particularly those with complaint of postmenopausal bleeding. ${ }^{10}$ The regulation and maintenance of normal tissue requires a balance between cell proliferation and programmed cell death, or apoptosis. When programmed cell death exceeds proliferation, the result is atrophy. When proliferation exceeds programmed cell death, the result is hyperplasia though many cytokines like TGF, b-FGF play critical role in it. ${ }^{11-12}$

Atypical endometrial hyperplasia is considered as a part of a continuum with endometrial cancer and this is of great concern as long as the uterus is in situ. ${ }^{13}$ During histopathological evaluation we faced similar problems as with other researchers happened i.e. accurate distinction between complex hyperplasia with atypia and endometrial carcinoma. ${ }^{14}$

Most cases of endometrial carcinoma of particularly of endometroid type are preceded by stage of hyperplasia. Hertig AT \& Sommers SC showed all patients with endometrial adenocarcinoma examined 15 years or less before development of adenocarcinoma had an abnormal endometrial pattern. ${ }^{15}$ So it is now a well established fact that early as well correct diagnosis of some merely benign histopathologic changes can save thousands of women from the curse of carcinoma. 
Depending upon nuclear and cytologic atypia women harbouring simple and complex hyperplasia were plotted again into four categories according to the latest WHO recomendations. ${ }^{16}$ Amongst the total 31 cases of our study total 9 cases $(29.03 \%$ ) were accompanied with nuclear atypia (five with simple and four with complex hyperplasia respectively).

From the experience we gathered we can say that inability to distinguish close entities like hyperplasia and carcinoma based on ultrasound alone should not be seen as a limitation because tissue sampling is a must in either case. We also opine that ultrasonography also may be used as a first line investigation in other populations with abnormal uterine bleeding.

Dijkhuizen et al. also opined that transvaginal ultrasonography is an excellent first-step diagnostic method for excluding the endometrial abnormalities in women particularly with postmenopausal bleeding. ${ }^{17}$ Regarding the thickness of endometrial layer there are different school of thought. How thick is too thick? - that remains as a point of debate for the sonologists. Ultrasonographic thickness of endometrium means maximum double thickness in longitudinal plane, i.e. the distance of the opposite bordering surfaces ofendometrium and myometrium. ${ }^{18}$ The procedure of measurements of endometrial thickness is simple in most cases. Normally, $5 \mathrm{~mm}$. thickness of the endometrium is taken as the cut-off value. Any value above this warrants extra attention (particularly in postmenopausal women). Nutis et al. studied the ultrasonographic thickness of endometrium of 112 postmenopausal women. ${ }^{19}$ They encountered maximum abnormal outcome between $5 \mathrm{~mm}$. and $9 \mathrm{~mm}$. They advised that sinologists should continue to use the $5-\mathrm{mm}$ cut point when deciding whether patients should have endometrial sampling or not. Weaver et al. recommended that endometrial thickness using a $5 \mathrm{~mm}$ cutoff is highly accurate in excluding endometrial disease even in symptomatic women taking tamoxifen and may negate the need for further diagnostic testing in women unless symptoms recur. ${ }^{20}$ Many other researchers suggest their own values, but conventionally $5 \mathrm{~mm}$. is taken as the cut-off value by most of the radiologists.

Keeping the same view with majority of the sonologists we also took $5 \mathrm{~mm}$. thickness as the cut off value in our study and it worked extremely well as the result almost in every case coincided with the histopathological diagnosis. In ultrasonographic measurement of all the hyperplastic endometrium in this study we got 29 out of 31 cases where the endometrial thickness was more than $5 \mathrm{~mm}$.(93.54\%). We got only two cases $(6.46 \%)$ where there was histopathological evidence of endometrial hyperplasia, but the ultrasonographic support was lacking as the thickness was less than $5 \mathrm{~mm}$. In most of the cases the endometrial thickness was in the range of $5-8 \mathrm{~mm}$. Their share was 21 cases $(67.74 \%)$. In the rest patients (9 cases) the endometrial thickness was more than $8 \mathrm{~mm} .(29.03 \%)$.

Among the 11 cases of endometrial carcinoma we found no case where the endometrial thickness was less than $5 \mathrm{~mm}$. The endometrial thickness was between $5-8 \mathrm{~mm}$. in three cases $(27.27 \%)$ and more than $8 \mathrm{~mm}$. in 8 cases (72.73\%). Thicknesses were $8.2 \mathrm{~mm}$., $9.3 \mathrm{~mm}$., $7.5 \mathrm{~mm}$., $11.2 \mathrm{~mm}$., $12.6 \mathrm{~mm}$., $8.6 \mathrm{~mm}$. (all were histopathologically endometrioid carcinoma), $7.3 \mathrm{~mm} ., 9 \mathrm{~mm}$., $6.8 \mathrm{~mm}$. (papillary serous carcinoma), $8.8 \mathrm{~mm}$. (squamous cell carcinoma) and $9.6 \mathrm{~mm}$. (clear cell carcinoma). On an average the endometrial thickness was $9.0 \mathrm{~mm}$.

Villavicencio et al. showed a very strong relation between obesity and overweight (in terms of BMI) and increased endometrial cell proliferation and finally endometrial carcinoma. ${ }^{21}$ They claimed the activation of AKT and ERK1,2 at the molecular level for the change. Viola et al. conducted a study in Brazil to determine the prevalence of endometrial hyperplasia and cancer in non-symptomatic overweight or obese women. ${ }^{22}$ They conducted a cross-sectional study amongst 193 women. The findings were classified as normal, hyperplasia or cancer, and the results were compared to body mass index. Their results showed that obese postmenopausal women have a high risk of developing endometrial hyperplasia or cancer.

We studied the Body Mass Index (BMI) of the study population. 45 cases (37.50\%) were obese in this study. 35 patients $(29.17 \%)$ were in the overweight group. We also found that obesity is a frequent entity for postmenopausal women. 31 cases $(25.83 \%)$ were healthy people. 9 cases $(7.50 \%)$ were found to be underweight.

Among the the 45 obese women endometrial hyperplasia was the predominant histologic variety. It included 22 cases which constituted $48.89 \%$ of the obese population. Similar result was found by Heller et $\mathrm{al}^{23}$ They performed a retrospective study with a total of 145 patients. While studying the BMI of the endometrial carcinoma patients we found that 7 out of 11 cases of endometrial carcinoma were obese. Mean value of BMI in all the endometrial carcinoma cases was 32.76. Patel et al. examined measures of physical activity in relation to endometrial cancer risk in the American Cancer Society Cancer Prevention Study II Nutrition Cohort, a prospective study of cancer incidence and mortality, using information obtained at baseline in $1992 .{ }^{24}$ From 1992 to 2003, 466 incident endometrial cancers were identified among 42,672 women. All measures of physical activity and the avoidance of sedentary behavior were associated with lower endometrial cancer risk.

Apart from endometrial hyperplasia other histopathologic varieties are proliferative endometrium (17.78\%), secretory endometrium (6.67\%), atrophic endometrium (8.88\%). Only one endometrial stromal sarcoma encountered in this study was found to be obese (BMI-34.5). 
Oestrogen deficiency after menopause precipitates a number of factors and these have established the 'menopausal metabolic syndrome' as a concept in postmenopausal women. Among the 36 hypertensive patients in our study 25 cases $(69.40 \%)$ were postmenopausal. The most predominant histopathologic variety among the hypertensives was endometrial hyperplasia (38.89\%). Five cases of endometrial carcinoma were hypertensive (13.89\%). Atrophic endometrium also encompassed a significant proportion (22.22\%). Vorgias et al. appreciated almost similar findings in their study. ${ }^{25}$ They concluded that endometrial thickening is significantly more frequent among the hypertensive women. Basically 3 out of 11 cases of endometrial carcinoma harbored both the risk factors.

In the whole study population 18 patients of diabetes mellitus (15.00\%). Out of these 18 patients 11 cases $(61.11 \%)$ were postmenopausal. Among this diabetic group the predominant histologic variety was endometrial hyperplasia; which constituted 9 out of 18 cases $(50.00 \%)$. 4 cases out of 18 diabetic $(22.22 \%)$ patients had endometrial carcinoma.

Among the 11 cases of endometrial adenocarcinoma we got 6 cases of endometrioid adenocarcinoma, 3 cases of papillary serous variety of adenocarcinoma, one each case of clear cell carcinoma and squamous cell carcinoma. Despite using morphometry and several other advanced techniques distinction between well differentiated endometrial carcinoma and severe hyperplasia (particularly complex with atypical features) two entities often posed an impediment to achieve the final diagnosis for many other researchers. ${ }^{26}$

We followed the FIGO 2009 staging and grading sysyem in our workup. Among the six cases of endometrioid carcinoma, four cases were of Grade 2 (i.e. solid component of the total non-squamous area in all the tumours were between 5\% and 50\%). In one case the solid component measured 60\% (Grade 3) and in the rest though the solid component was $40 \%$ though the grade of the tumour was upgraded by one step (Grade 3) as there were high degree of nuclear atypia (according to FIGO 2009 system). The metaplastic squamous component was present in two cases of endometrioid carcinoma. In either case none of which was malignant.

Regarding staging only six cases out of 11 carcinomas were diagnosed in St.I. Amongst the rest cases four patients were diagnosed in St.III and one in St.II. It reflects that early as well as accurate diagnosis is how much important in ultimate outcome of these cases because often this neoplasia wraps the body intimately but unknowingly. Roughly stage at diagnosis seems to be comparatively higher in postmenopausal patients in respect to their perimenopausal counterpart.

We got a case of endometrial stromal sarcoma in a lady aged 44 year. She presented with postmenopausal bleeding. Microscopically, we found bland oval stromal cells arranged concentrically around the arterioles. Neoplastic endometrial stroma was seen to lie in plenty between the muscle bundles of myometrium. Immunohistochemistry was done to confirm the diagnosis. Immunostaining with CD 10 showed strong positivity and caldesmon was negative.

\section{Tables And Figures}

\begin{tabular}{|c|c|c|c|c|c|}
\hline PARAMATERS & CASE 1 & CASE 2 & CASE 3 & CASE 4 & CASE 5 \\
\hline$\overline{\overline{A G E} \text { (IN YRS.) }}$ & 50 & 48 & 59 & 68 & 59 \\
\hline $\begin{array}{l}\text { AGE AT } \\
\text { MENARCHE }\end{array}$ & 12 & 10 & 11 & 10 & 10 \\
\hline $\begin{array}{l}\text { MENOPAUSE } \\
\text { ACHIEVED OR } \\
\text { NOT }\end{array}$ & $\begin{array}{l}\text { Postmeno- } \\
\text { pausal }\end{array}$ & $\begin{array}{l}\text { Postmeno- } \\
\text { Pausal }\end{array}$ & $\begin{array}{l}\text { Postmeno- } \\
\text { pausal }\end{array}$ & $\begin{array}{l}\text { Postmeno- } \\
\text { pausal }\end{array}$ & $\begin{array}{l}\text { Postmeno- } \\
\text { Pausal }\end{array}$ \\
\hline $\begin{array}{l}\text { AGE OF } \\
\text { MENOPAUSE }\end{array}$ & 46 & 45 & 41 & 46 & 46 \\
\hline $\begin{array}{l}\text { PRESENTING } \\
\text { COMPLAINT }\end{array}$ & $\begin{array}{l}\text { Postmeno-pausal } \\
\text { bleeding }\end{array}$ & $\begin{array}{l}\text { Postmeno-pausal } \\
\text { bleeding }\end{array}$ & $\begin{array}{l}\text { Postmeno-pausal } \\
\text { bleeding }\end{array}$ & $\begin{array}{l}\text { Postmeno-pausal } \\
\text { bleeding }\end{array}$ & $\begin{array}{l}\text { Postmeno- } \\
\text { pausal bleeding }\end{array}$ \\
\hline $\begin{array}{l}\text { ENDOMETRIAL } \\
\text { THICKNESS IN } \\
\text { USG }\end{array}$ & $8.2 \mathrm{MM}$. & 9.3MM. & $7.5 \mathrm{MM}$. & $9.6 \mathrm{MM}$. & 8.8MM. \\
\hline $\begin{array}{l}\text { WHETHER CA } \\
\text { WAS } \\
\text { PRECEEDED BY } \\
\text { HYPERPLASIA }\end{array}$ & No & Yes & Yes & No & No \\
\hline $\begin{array}{l}\text { HISTOLOGICAL } \\
\text { TYPE }\end{array}$ & $\begin{array}{l}\text { Endometrioid } \\
\text { endometrial } \\
\text { adenocarcinoma }\end{array}$ & $\begin{array}{l}\text { Endometrioid } \\
\text { endometrial } \\
\text { adenocarcinoma }\end{array}$ & $\begin{array}{l}\text { Endometrioid } \\
\text { endometrial } \\
\text { adenocarcinoma }\end{array}$ & $\begin{array}{l}\text { Papillary serous } \\
\text { endometrial } \\
\text { adenocarcinoma }\end{array}$ & $\begin{array}{l}\text { Squamous cell } \\
\text { carcinoma of } \\
\text { the } \\
\text { endometrium }\end{array}$ \\
\hline $\begin{array}{l}\text { ANY } \\
\text { METAPLASIA }\end{array}$ & NIL & NIL & Benign squamous & NIL & NIL \\
\hline $\begin{array}{l}\text { \% OF SOLID } \\
\text { COMPONENT(IN } \\
\text { NONSQUAMOUS } \\
\text { AREA) } \\
\end{array}$ & $20 \%$ & $35 \%$ & $60 \%$ & - & - \\
\hline
\end{tabular}


Clinicopathological study of endometrium in peri and postmenopausal women in a tertiary care

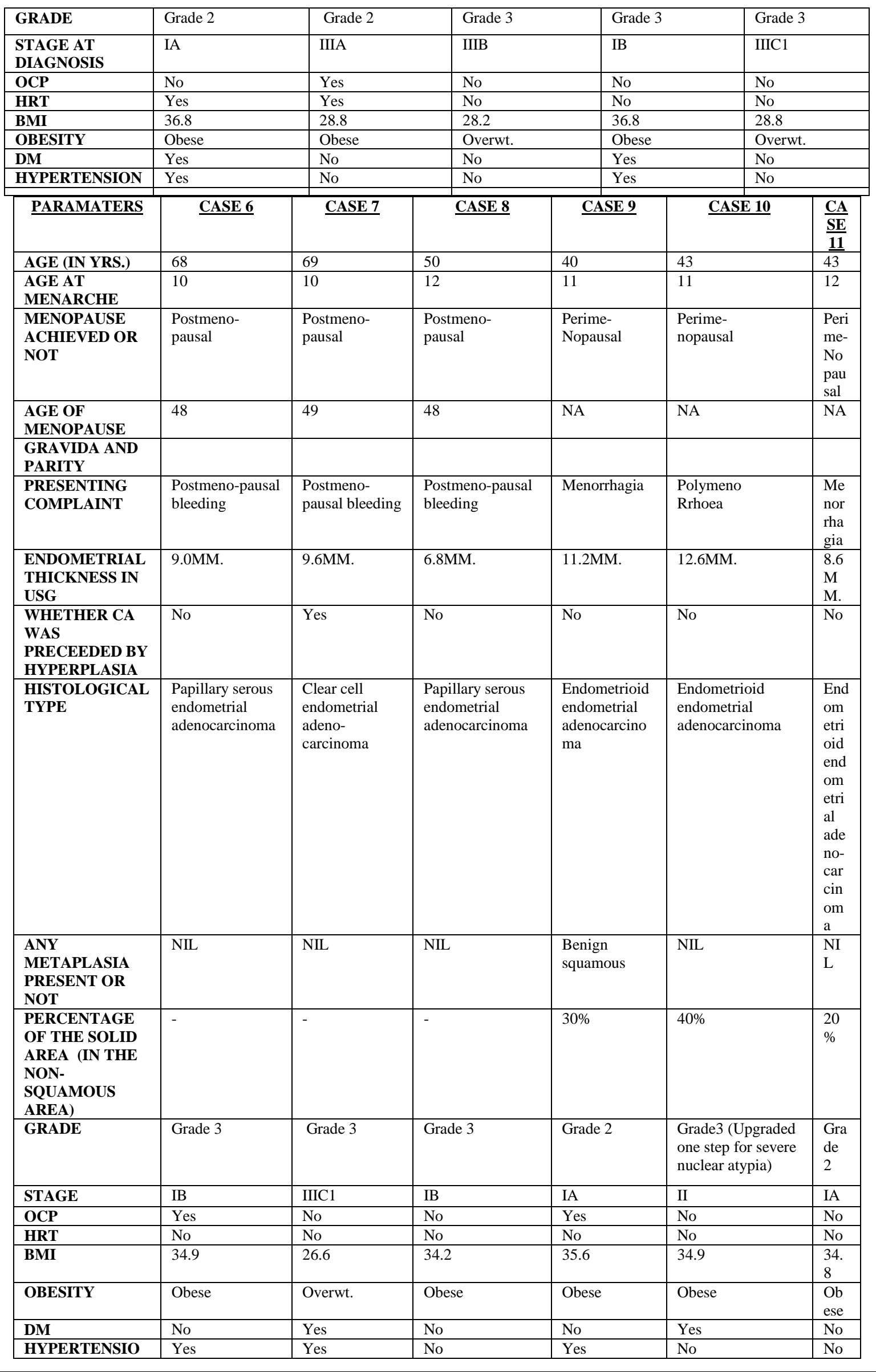




\begin{tabular}{|l|l|l|l|l|l|}
\hline $\mathbf{N}$ & & & & & \\
\hline
\end{tabular}

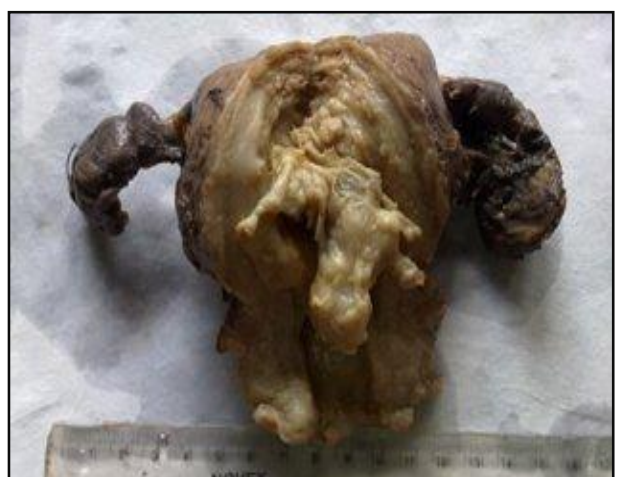

FIGURE1 Cauliflower-like growth protruding out

from the endometrial cavity.

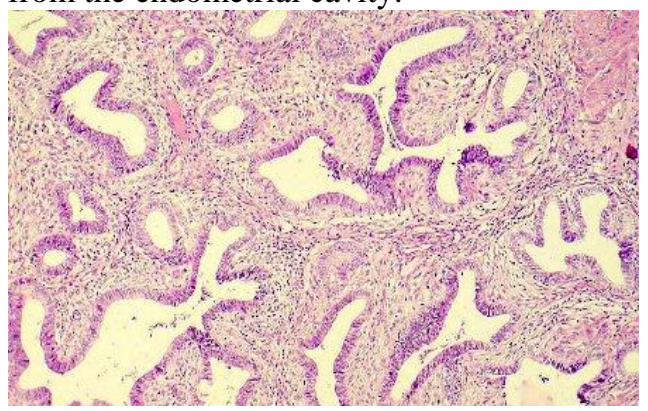

FIGURE3 Complex endometrial hyperplasia sarcoma.

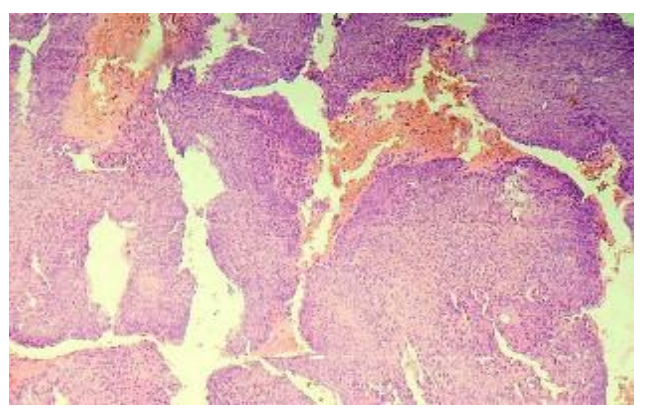

FIGURE5:Squamous cell carcinoma endometrium(H\&E100X) carcinoma(H\&E100X)

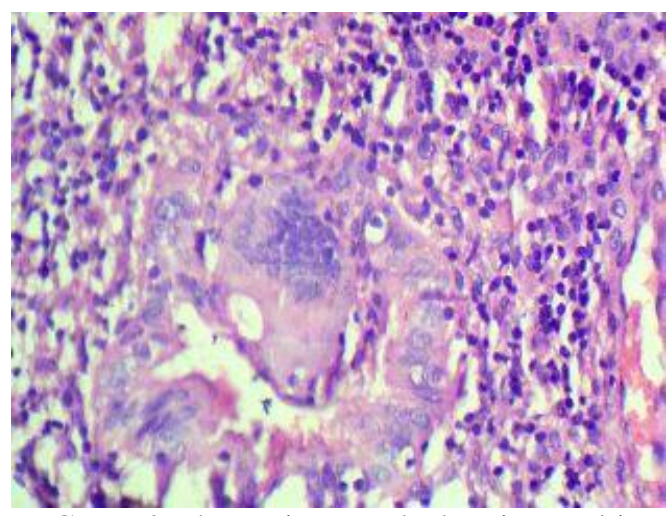

FIGURE2 Photomicrograph showing multinucleated Giant cell with caseous necrosis in endometrium-Endometrial tuberculosis. (H \& E,400X).

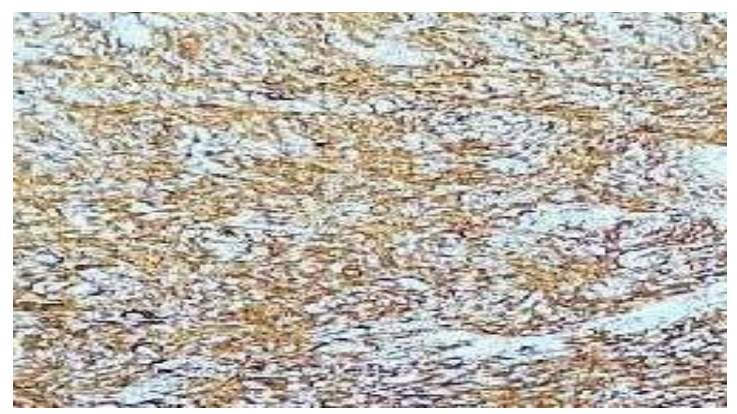

FIGURE4Strong CD10positivity in stromal

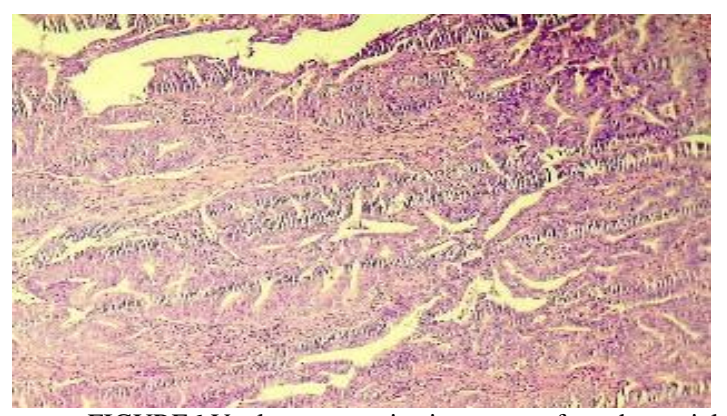

FIGURE6:Vault metastasis in case of endometrial

\section{References}

[1]. Current Diagnosis and Treatment in Gynaecology and Obstretics. Alan H. DeCherney, Lauren Nathan. $8^{\mathrm{TH}}$ Ed. 2003;Page -135-6.

[2]. Jabbour HN. Endocrine regulation of menstruation. Endocr Rev 2006;27:17.

[3]. Treloar AE, Boynton RE, Borghild GB et al. Variation of the human menstrual cycle through reproductive life. Int J Fertil 1967;12:77-126.

[4]. Collett ME, Wertenberger GE, Fiske VM. The effects of age upon the pattern of the menstrual cycle. Fertil Steril 1954;5:437-48.

[5]. Berek \& Novak's Gynaecology. Jonathon S Berek. 14 ${ }^{\text {th }}$ Edition;Page-1324

[6]. Jillani K, Khero RB, Maqsood S, Siddiqui MA. Prevalence of malignant disorders in 50 cases of postmenopausal bleeding. J Pak Med Assoc. 2010;60:540-3.

[7]. Gredmark T, Kvint S, Havel G et al. Histopathological findings in women with postmenopausal bleeding. BJOG 1995;102:133-6.

[8]. Dawood NS, Peter K, Ibrar F, Dawood A. Postmenopausal bleeding: causes and risk of genital tract malignancy. J Ayub Med Coll 2010;22:117-20.

[9]. Lee WH, Tan KH, Lee YW. The aetiology of postmenopausal bleeding-a study of 163 consecutive cases in Singapore. Singapore Med J 1995;36:164-8.

[10]. Mukhopadhayay S, Bhattacharyya SK, Ganguly RP, Patra KK, Bhattacharya N, Barman SC. Comparative evaluation of perimenopausal abnormal uterine bleeding by transvaginal sonography, hysteroscopy and endometrial biopsy. J Indian Med Assoc 2007;105:624-8. 
[11]. Gold LI, Saxena B, Mittal KR, et al. Increased expression of transforming growth factor B isoforms and basic fibroblast growth factor in complex hyperplasia and adenocarcinoma of the endometrium: evidence for paracrine and autocrine action. Cancer Res 1994;54:2347-58.

[12]. Leake R, Carr L, Rinaldi F. Autocrine and paracrine effects in the endometrium. Ann N Y Acad Sci 1991;622:145-8

[13]. Management of endometrial cancer. ACOG Practice Bulletin No.65. American College of Obstetricians and Gynecologists. Obstet Gynecol 2005; 106:413-25.

[14]. Silverberg SG: Problems in the differential diagnosis of endometrial hyperplasia and carcinoma. Mod Pathol 2000;13:309.

[15]. Hertig AT, Sommers SC. Genesis of Endometrial Carcinoma I. Study prior biopsies. Cancers 1949;2:946-56.

[16]. Kurman RJ, Kaminski PF, Norris HJ. The behavior of endometrial hyperplasia: a long term study of "untreated" hyperplasia in 170 patients. Cancer 1985;56:403-12.

[17]. Dijkhuizen FP, Brölmann HA, Potters AE, Bongers MY, Heinz AP. The accuracy of transvaginal ultrasonography in the diagnosis of endometrial abnormalities. Obstet Gynaecol 1996;87:345-9.

[18]. Curcić A, Segedi D, Belopavlović Z, Petrović D. Transvaginal sonography of the postmenopausal endometrium. Med Pregl 2000;53:59-63.

[19]. Nutis M, García KM, Nuwayhid B, Mulla Z, ElMasri W. Use of ultrasonographic cut point for diagnosing endometrial pathology in postmenopausal women with multiple risk factors for endometrial cancer. J Reprod Med 2008;53:755-9.

[20]. Weaver J, McHugo JM, Clark TJ. Accuracy of transvaginal ultrasound in diagnosing endometrial pathology in women with postmenopausal bleeding on tamoxifen. Br J Radiol 2005;78:394-7.

[21]. Villavicencio A, Aguilar G, Argüello G, Dünner C, Gabler F, Soto E, Gaete F, Peñaloza P, Celis M, Rojas C. The effect of overweight and obesity on proliferation and activation of AKT and ERK in human endometria. Gynecol Oncol 2010;117:96-102.

[22]. Viola AS, Gouveia D, Andrade L, Aldrighi JM, Viola CF, Bahamondes L. Prevalence of endometrial cancer and hyperplasia in non-symptomatic overweight and obese women. Aust N Z J Obstet Gynecol 2008;48:207-13.

[23]. Heller DS, Mosquera C, Goldsmith LT, Cracchiolo B. Body mass index of patients with endometrial hyperplasia: comparison to patients with proliferative endometrium and abnormal bleeding. J Reprod Med 201;56: 110-2.

[24]. Patel AV, Feigelson HS, Talbot JT, McCullough ML, Rodriguez C, Patel RC, Thun MJ, Calle EE. The role of body weight in the relationship between physical activity and endometrial cancer: results from a large cohort of US women. Int J Cancer $2008 ; 123: 1877-82$

[25]. Vorgias G, Strigo S, Varhalama E, Savvopoulos P, Dertimas B, Akrivos T. The effect of hypertension and anti-hypertensive drugs on endometrial thickness and pathology. Eur J Obstet Gynecol Reprod Biol 2006;125:239-42.

[26]. Norris HJ, Becker RL, Mikel UV. A comparative morphometric and cytophotometric study of endometrial hyperplasia, atypical hyperplasia and endometrial carcinoma. Hum Pathol 1989;20:219-23. 